\title{
Difficulties of Learning English Language at the Secondary Level: A Case Study of Thakurgaon District
}

\author{
Md. Amir Hossain (Corresponding Author) \\ M.Phil. Research Scholar, Department of English \\ Jahangirnagar University, Bangladesh \\ Mobile: +8801915908306Ｅ-mail: amir.hossain.16578@gmail.com
}

Received: April 18, 2018

Accepted: May 28, 2018

Published: August 14, 2018

doi:10.5296/jet.v5i2.13500

URL: http://dx.doi.org/10.5296/jet.v5i2.13500

\begin{abstract}
The aim of this paper is to examine the complexities of learning English Language among the SSC level learners of Lahiri High School under Thakurgaon District, a northern part of Bangladesh. Many students don't receive Standard Education of English due to knowledgeable teachers, financial constraints, lack of multimedia project teaching and learning system, and lack of English Language Club. It aims to look at motivating the young learners so that they can be able to develop the basic knowledge of four skills despite depriving of ultra-modern facilities. For this purpose, the current researcher collected date through questionnaire and interview process. 15 sets of questions were provided among 15 students to find out their fundamental knowledge of English language. In the field survey, 31 participants were selected for interview, including 15 male \& female students, 6 teachers, and 10 guardians. Teachers and parents expressed their different views about English language learning complexities. Participants responded that students were weak in English Grammar, Vocabulary, and Speaking Skill. After realizing their English learning complexities, the researcher came to conclusion and recommendations. Thus this study would like to show a new dimension of English Language Learning for the Secondary Level students at Thakurgaon District in Bangladesh.
\end{abstract}

Keywords: English Language, SSC level learners, Thakurgaon District

\section{Introduction}

English is an international language. The demand of English is on the increase day by day. Its necessity can't describe in word or in language. We can't think of our existence without English. To develop Education System of a country, the role of English language can't be ignored. So syllabus design, lesson plan, examination system, and script evaluation should be prepared in such a way that the younger generation would come up the ultra-modern policy 
implementation project. If this ground starts at the Secondary level, many young learners can be able to increase their knowledge of English language. And, students and teachers will be able to get rid of English learning difficulties.

When children first acquire a new foreign language, their reaction to the encounter is various, mainly, because it is more or less unlike their native language. Foreign language has very often different structure, rules, system etc. What happens is that some children easily cope with the language, some need time to develop their skill; and some struggle with it from the beginning. Those who start to have difficulties with learning a foreign language can be either children who have a learning disability or those who do not have any disability, but still show learning difficulties in the foreign language.

Anyway, as far as this study is concerned, its purpose is to consider the young learners at the Secondary Level who were not diagnosed with a learning disability, but still have significant difficulties in learning a foreign language, like English. The subject of the study is focused on the analysis of difficulties while learning English Language in the classroom.

The above mentioned analysis is partly grounded on a hypothesis that the teaching process and methods are practiced to teach the young learners with learning difficulties through mastering English as a foreign language from the beginning of the early stage of life.

The aim of the study is to provide practical examples of methods that would improve and encourage the young learners to learn English as a foreign language with minimum difficulties. Its aim is to look at finding out the difficulties along with some effective steps so that the SSC level students can be properly benefitted in learning English Language for their real life situations.

For this purpose, the current researcher collected date through questionnaire and interview process. 15 sets of questions were provided to 15 learners of SSC Level to tick the alternative options from a, b, c, d. In the field survey, there were 31 participants who participated in the interview, including-15 male \& female students, 6 teachers, and 10 parents. Teachers and parents expressed different views of English language learning complexities. Most of them responded that students were weak in English Grammar, Vocabulary, and Speaking Skill. After analyzing their English language learning complexities, the researcher came to conclusion through recommendations and some fruitful steps. In this way, it would like to unveil a new dimension of English language learning for the Secondary Level students in $21^{\text {st }}$-century Bangladesh Education System Context.

\section{Background of the Study}

Before analyzing teaching methods that support young learners with learning difficulties in English as a foreign language, the main attention should be drawn to the process of learning language in general.

Very interesting results were revealed by Joan Tough, who has a lifetime's experience in language teaching as a primary school teacher. Her research and her practice show that there is a connection between learning one's mother tongue and learning a foreign language. 
The fact that young children learn their first language with such speed and competence must mean that if the process can be better understood it should be possible to design experiences through which children learn a second language in much the same way as they learn their first language. (Tough, 1984, p. 213)

The explanation can be seen in "the potential for social and cognitive development" (p.213) during the early stage of life. Children's potentiality begins to broaden in interacting with others, mainly with parents, is intensive and children experience the language. This communication is, initially, based on children's non-verbal reactions (e.g. gestures, facial expression, actions and vocalizations) and later the first verbal responses are presented. The stage of verbal communication is preceded by a long process of gaining experiences for learning a second language.

\section{Learning Strategies}

The major problems of teaching and learning English at the secondary level are lack of teacher's training course, appropriate teaching materials, proper infrastructure, lack of efficient teachers, teachers' motivation, lack of proper experience of teaching, lack of scientific teaching method, and lack of ELT research.

Overemphasis on the grammatical accuracy, much preference given to Bengali in teaching English, limited scope for practices are some other complexities. Among them, lack of teacher's training is one of the major problems found to teach English in the Secondary Level. There is a lack of training opportunities for teachers of this level; and most English teachers are reluctant to be trained up. They always sneer at the teacher's training. The teachers without training believe that they know much more than the trainers. Their conceit kills themselves; and the dormant potentials of the learners. Besides, the appointment procedures of teachers in the secondary level are not transparent. In many cases, the appointment of a teacher depends on money not upon merit. Some teachers are recruited in a political way though they are not conversant with English. Consequently, most of the teachers are seen to be insincere and inattentive in their classroom. They teach the learners without any plan or target in mind. They do not have any knowledge of cognitive teaching methods and techniques. So, they never motivate the learners to practice four skills of English inside and outside the class. Instead, they encourage the learners to go to private tutorial home. This evil intention is seen every nook and corner throughout the country. If this situation goes on, a large portion of learners will gradually be idle and inactive. Their brain will be paralyzed one day. Although they pretend to learn English, they will never learn it.

To provide the learners' maximum benefit and to make the class effective and enjoyable, teachers should involve the students in a variety of activities, such as group work, pair work, role play, question-answer, discussion, debating, etc. Textbook should be followed strictly. Classes should be participatory and teacher-student-oriented. Tasks should be interesting and relevant to the learners' life and environment. All four basic skills of English language would be practised in the classrooms in an integrated manner, not in isolation. Grammar would be taught through the communicative approaches. Some language games, puzzles, and jokes may be used as exercises for developing students' language skills through fun and 
entertainment. In every class, new vocabulary would be introduced.

The first stage of acquiring a language is Imitation. The imitation is used while trying to produce speech by imitating single words that are used by others. When the meaning of any word/phrase is attached, children start to use them frequently and repeat them in terms of practice.

The second stage is Repetition when "children respond to a parent's comment by repeating what has been said before going on to formulate a response" (Tough, 1984, p.224). This helps learners recognize the structure of the utterances.

A further step of the learning strategy is called Formulaic Speech. This stage is reached when learners learn and continuously use short phrases that are attached to certain everyday-life situations.

The final stage of the learning strategy is Incorporation which is based on "taking the form of repeating a word or short phrase used by the adult and putting it in some sequence with elements already established" (p.224). This leads towards recognizing principles of the language use.

\section{Literature Review}

Nasrin (2008) made a view that more than a decade has passed since beginning of the CLT approach in Bangladesh. Nevertheless, not enough facilities are of computer, of photocopier, and of audio-visual support in every school; Classroom size is very large - more than 200 students in one class.

Islam (2003) and Rahman (2010) argued that the ELT teachers in Bangladesh received inadequate support and training from the authority in order to cope with the changes in the curriculum.

Hamid (2011) expressed his view that the main reasons for the failure of successful ELT are rooted in state policy and planning. During the beginning of post-independence Bangladesh in 1970s, state policy delimited the scope, use, and growth of English in Bangladesh by overemphasizing the national language Bangla. Almost twenty years later (1990s), after a realization of the importance of English, an emphasis on English went beyond the actual implementation capacity of Bangladesh. The early start of learning English from Class 1 in the national curriculum requires lots of resources from the state, which cannot be justified both for pedagogic and economic reasons. On one hand, this ambitious language policy caused a huge loss of national resources that had already been spent on the teaching and the learning of English.

Brown (1994) commented that communication is likely to occur in the classroom when: (1) a significant amount of pair work and group work is conducted; (2) authentic language input in real life context is provided; (3) students are encouraged to produce language for genuine, meaningful communication; and (4) classroom tasks are conducted to prepare students for actual language use outside the classroom. 


\section{Review and Forgetting Curve}

The key process that bridges the gap between learning and acquisition is review. Review is a process of practicing what has been presented to master the knowledge of English. Young learners with learning difficulties would be given enough opportunities and even time to repeat through a variety of exercises and activities. Certain teaching methods can be applied to support review.

One example of the 'from learning to acquisition' process can be seen on the 'forgetting curve' that shows the process from first learning to acquisition. There is a timeline that illustrates the time of mastering (acquiring) a certain amount of knowledge. The first 'forgetting curve' expresses how much learners would remember during the period if they did not review anything.

\subsection{Difficulties of Learning English Language at Thakurgaon District}

Thakurgaon is a district of North Bengal in Bangladesh. This district is segregated from the capital city, Dhaka. The standard of education is not highly developed, especially in the Secondary and Higher Secondary Level of Thakurgaon district. The name of the Education Board is Dinajpur Education Board, which is very small in comparison with other boards of the country. Though there are many school \& colleges in this district, most of the students don't get proper education at all. The economic condition of the students beggars description. Their parents fully rely upon the mercy of agriculture. There is no alternative means without agriculture. The expense of education totally comes from the income source of agriculture. Most of the people of this district are poor and uneducated. They cannot afford to educate their children in the proper way. Students have to face difficulties in learning English language; they are deprived of expert English teachers; they have no proper basic knowledge of grammar, vocabulary, and speaking skill.

For this purpose, the aim of this study aims to look at the difficulties of learning English language among the Secondary Level Learners of Thakurgaon District. So, the researcher has emphasized upon some major complexities why the learners are deprived of knowledge of English language. Also some effective steps were investigated how to solve English learning difficulties in order that the secondary level learners can be motivated to develop their knowledge of English Language. Here, in this study, I have tried to emphasize on some complexities of learning English along with their probable steps. They are as follows:

\subsubsection{Lack of English Teacher}

There is a lack of a good English teacher Thakurgaon still now. Many teachers are politically recruited at school. Some are appointed in taking donation by the local politicians, the Chairman and the Managing Committee of the Institution. Written test \& interview are showy system at Thakurgaon. If teachers are not conversant with English language, how a nation can expect that students receive standard education from them. Teachers have no proper sense of English Grammar, Vocabulary, and above all, four skills of English language. Even many teachers don't know how to speak English at all while they teach English in the class. If this situation is continued, Secondary Level learners fail to learn English properly. 


\subsubsection{Steps}

The Government should take proper steps while any teachers are recruited, especially for English, Math, and Science. The local leaders and Managing Committee should come forward not to take bribe while teachers are recruited. Rather they should have sensibility of recruiting expert English teachers at school so that the young learners can be able to acquire the basic knowledge of English Language and also they can compete with the age.

\subsubsection{Lack of English Language Club}

There is no English Language Club throughout the district. Generally, we know that there is no alternative way without English Language Club if any student dreams to speak, write, or read. He must go to the English Club; his academic learning is not enough since teacher are not well-trained and expert. To develop the knowledge of English, it plays an important role for the students' performance on four skills of English language.

\subsubsection{Steps}

Since the role of English Language Club is no less important in learning English, the concerned authority must take pragmatic steps to found such club across the district so that students can increase their knowledge of English. Students must be motivated to join in the club, for this task the concerned authority should take steps to establish English Language Club.

\subsubsection{Economic Constraints}

Since ours is a very poor country, so we have to face economic constraints throughout the country. People living at Thakurgaon district have to maintain their livelihood, depending on the mercy of agriculture. Their income source comes from agriculture; based on the agriculture, they educate their children. The majority of the people are farmers; they are very poor and illiterate. In a word, it can be written that they don't know how to or what to read and write. Due to poverty, many of them drop out from the long cherished dreams despite merit. They never think of higher education let alone secondary education. Thus economic constraints hinder their dream and expectation when they want to proceed further.

\subsubsection{Steps}

The Government as well as the conscious people of the country should raise their helping hands to assist the large population living at Thakurgaon so that the parents can afford to educate their children. To accomplish this difficult task, they must be inspired to increase their knowledge of science and technology besides agriculture. The Government should create employment opportunities for the poorer communities of Thakurgaon district so that their children can be able to receive proper knowledge of English.

\subsubsection{Lack of Multimedia Projector}

At Thakurgaon district, there is no use of multimedia project at all while teachers teach their students in the class. Even they have no common knowledge how to use multimedia. In the $21^{\text {st }}$-century age, if we look at the secondary level institutions of the economically developed countries of the globe, we will see that no teacher can be allowed to take classes without multimedia projectors. But the scenario is totally opposite in our country. There is no multimedia project teaching system in the classroom. As a result, a large number of students 
are fully deprived of multimedia project learning system.

\subsubsection{Steps}

Since students don't receive multimedia project learning in the field of education system, the concerned authority should ensure the very fact so that multimedia projector can be established in all classes to develop education policy. Teachers should receive training course on the usage of multimedia project in the classroom.

\subsubsection{Lack of Road Communication}

Thakurgaon is a/an small and underdeveloped district in comparison with other parts of the country. Here the road communication system is not properly developed; many students live in the remote villages, which are deprived of the light of education. The poor of the poorest people reside and keep body and soul together under the scorching sun. Many female students don't dare to go to school due to a long distance. Sometimes the innocent girls fall victim of eve-teaching, rape, kidnapping and so on. Such occurrences are found almost all the year round. If these incidences occur due to poor road communication system, how the young learners will be able to study.

\subsubsection{Steps}

The local authorities must come forward in this regard to develop the road communication system. They should remember that their own children are studying at school and college. They should inform the matter of the local government so that road communication system can be developed. Institutions should be established near the high-tech communication in order that students can easily be able to keep communication with teachers and institutions. To develop the road communication system, all's participation is a must.

\section{Hypothesis}

The above mentioned analysis is partly grounded on a hypothesis that the teaching process and methods that would be practised teaching students with learning complexities can be adopted to support the young learners with learning difficulties in order that students can master English as an international language from the beginning of their early stage of life. For this purpose, this study was conducted to focus upon the mixed methods so that the researcher would be able to find out the means of solving English learning complexities.

\section{Methodology \& Data Collection}

The research paper is based upon qualitative, quantitative method and questionnaire process. The important sources have been taken from the library, like books, journals, thesis, and other necessary sources. It is a theoretical one that presents objectives, options, and arguments concerning the teaching and learning approaches that are applied to minimize learning difficulties of the secondary level learners at Lahiri High School under Thakurgaon district.

Firstly, the study was carried out to highlight the background of English Language Learning with particular accent on methods which was applied for teaching the young learners with learning complexities. This background part was divided into some subcategories: the first one concern the process of learning from the young learner's point of view, and the other one was centered on the teaching and learning approaches. 
Secondly, the work presented practical conclusions about the issue as well as useful and applicable materials for the teachers who teach the young learners along with learning complexities in the classroom. So, the study unveils findings and recommendations with a view to improving the techniques of learning a Foreign Language, like English for the students of SSC Level at Lahiri High School under Thakurgaon district.

In this qualitative method, data on teaching English as a foreign language to students with learning complexities were collected from different types of male and female learners of SSC level. In this field survey, 15 students did take an active part at Lahiri High School. 15 worksheets of multiple choices were provided to the hands of the participants. They were given 30 minutes to tick the appropriate answers from the alternatives. The sample for the parents was a convenience sample as some of them were willing to express their attitudes towards English language learning complexities face to face while the interview was being taken. The participants were asked to answer the multiple choice questions. Through the field survey form, the reasons for English language learning difficulties were connected to the task done among the SSC level students at Lahiri High School, their assigned teachers and other important information about English language learning complexities were investigated. Further clarifications were done through the interview with other students, teachers, and guidance. The students were asked to fill the survey form relating to the reasons for English language learning complexities, how teachers helps the students of the SSC level understand English grammatical knowledge, reading comprehension, composition, application, paragraph, letter, story writing, and script evaluation. The researcher had to spend 7-10 days to collect data so that he could enable to show a faithful picture of English language learning complexities among the SSC level students. Also, the researcher proposed the topics for discussion during the interview process, but asked few specific questions.

According to Rubin \& Rubin (1995), during each of the interviews, the researcher recorded the interview and prompted the participants to express what they thought were the reasons of English language learning complexities. The format of the different types of interviewing process was open, some participants responded with more details, while others simply agreed with what had been said. Students' and parents' interviews lasted for approximately 3 hours and 2 hours, respectively. After the interviews were completed, the researcher went through the hand sheets, and transcribed the two interviews by noting complete thoughts and helpful information.

\section{Data Analysis}

The content of the participants' responses in different types of interviews was investigated and coded. According to Rubin and Rubin (1995), "Coding is the process of grouping interviewees' responses into categories that bring together the similar ideas, concepts, or themes you have discovered". (p. 238) in coding the interview data, the researcher marked the answer in the form of a, b, c, d option that caught his attention and that had potential to serve as a category. This procedure enabled the researcher to gather new information into categories or central themes, including giving those marks through tick mark system. Participants of the SSC level, and their parents' groups did express different views about the 


\section{IIMacrothink}

causes of English language learning complexities. Responses from the participants were compiled and problems and reasons for learning English language from the data.

\begin{tabular}{|c|c|c|c|c|}
\hline $\begin{array}{c}\text { Ques. } \\
\text { No }\end{array}$ & $\mathrm{a}$ & $\mathrm{b}$ & $\mathrm{c}$ & $\mathrm{d}$ \\
\hline $\mathbf{1}$ & 5 & 4 & 2 & 4 \\
\hline $\mathbf{2}$ & 6 & 7 & 0 & 0 \\
\hline $\mathbf{3}$ & 3 & 6 & 4 & 2 \\
\hline $\mathbf{4}$ & 2 & 5 & 4 & 4 \\
\hline $\mathbf{5}$ & 7 & 3 & 3 & 2 \\
\hline $\mathbf{6}$ & 2 & 3 & 3 & 7 \\
\hline $\mathbf{7}$ & 3 & 0 & 15 & \\
\hline $\mathbf{8}$ & 3 & 5 & 4 & 3 \\
\hline $\mathbf{9}$ & 5 & 5 & 3 & 2 \\
\hline $\mathbf{1 0}$ & 3 & 5 & 6 & 1 \\
\hline $\mathbf{1 1}$ & 4 & 11 & 0 & 0 \\
\hline $\mathbf{1 2}$ & 7 & 3 & 3 & 2 \\
\hline $\mathbf{1 3}$ & 6 & 7 & 2 & 0 \\
\hline $\mathbf{1 4}$ & 3 & 5 & 6 & 1 \\
\hline $\mathbf{1 5}$ & 3 & 6 & 3 & 2 \\
\hline Total & $\mathbf{6 2}$ & $\mathbf{7 5}$ & $\mathbf{5 8}$ & $\mathbf{3 0}$ \\
\hline
\end{tabular}

\section{SSC level Students' Survey Questionnaire}

From this chart it is seen that there were 15 male and female participants in the test. Question set was provided to the students in the classroom activities at Lahiri High School. There were four options in the question pattern. 15 sets of question were given to each student in the class. It took 30 minutes to answer the question. Then the questions were taken from them. While the researcher scrutinized their questions very careful, it was found that most of the students gave the tick mark on ' $b$ ' option whose total summation was 75 . Then they chose 'a' option which was 62, and ' $c$ ' was the third choice and ' $d$ ' was the least choice option. The survey showed that ' $b$ ' option was the highest choice of the students and ' $d$ ' option was their lowest choice which was only 30. In this way the researcher investigated English language learning complexities through questionnaire and interview process at Thakuraon district. 


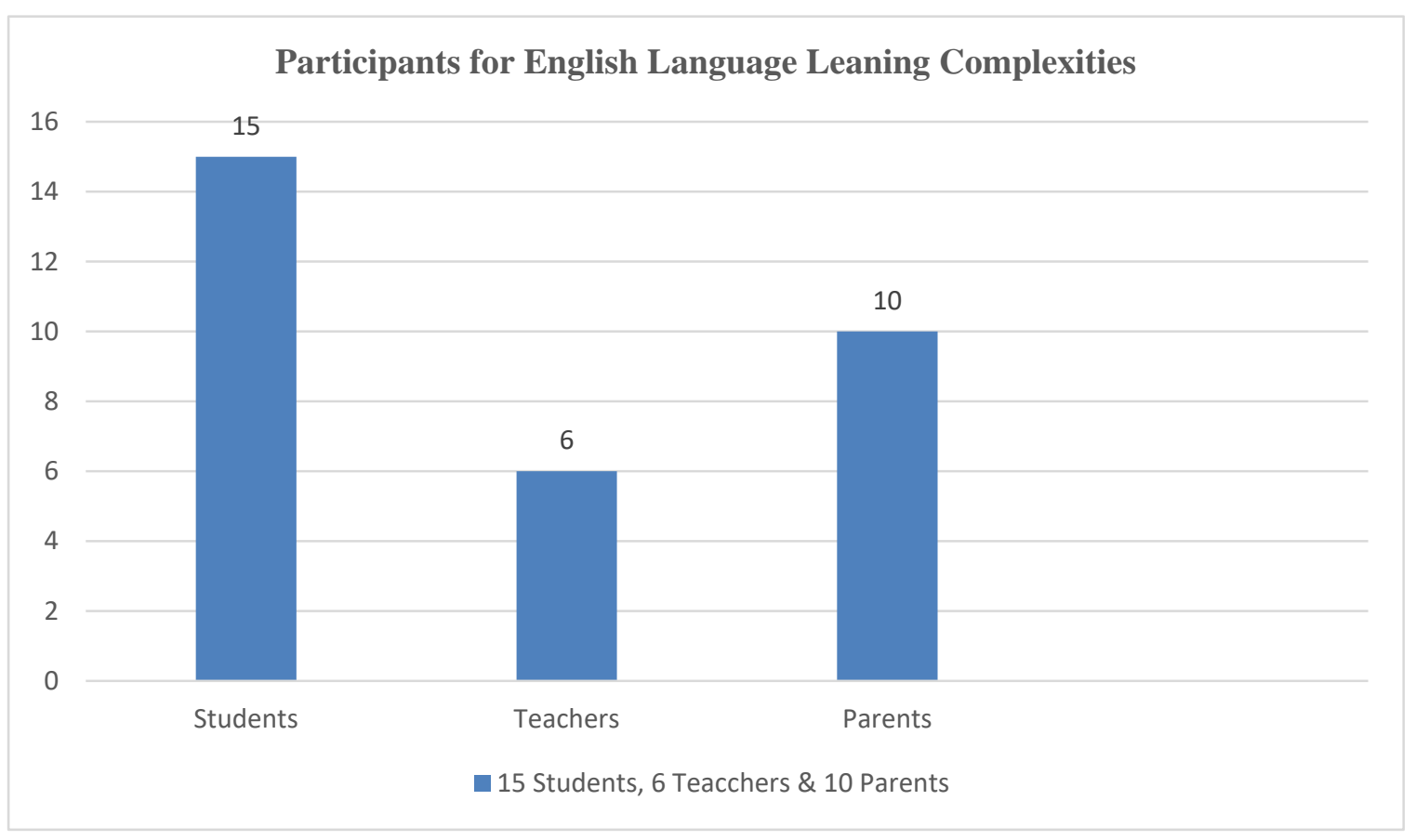

In the graph, it is seen that there were 31 participants who participated in the interview as well as questionnaire system. They were as follows: 15 male \& female students, 6 teachers, and 10 parents. Teachers and parents did their comments regarding English language learning complexities in different ways. Most of them responded that students were weak in English Grammar, Speaking, and vocabulary. They have failed to develop grammatical knowledge due to expert English teachers. While taking the interview, it was found that some students did not understand the meaning of questions and a, b, c, d option very clearly since the question set was in English version. They expressed that they had vocabulary \& grammatical problem in learning English Language. The survey showed that teachers were not good at vocabulary \& grammar as well. They practised traditional method instead of CELT in the classroom activities.

\section{Findings}

From this research-work, the current researcher has gathered also some pragmatic experiences regarding the difficulties of learning English language among the Secondary Level Learners at Lahiri High School under Thakurgaon district. Most of the students are very weak in English Grammar, Vocabulary, and Speaking Skill. They don't know how to or what to speak English with others. Their spoken fluency is very poor, one kind of ' 0 ' level can be mentioned; even some teachers of English have no fluency in speaking skill. While the teachers take classes, they use local language, like Bengali. When they were questioned about difficulties of learning English language, they didn't understand properly about questionnaire pattern. From the students' point of view, it was found that teachers always use Bengali language in the English classes. Most of the students come of a very poor family; they have no capability to learn English from private tutoring system on account of financial crisis; they have to depend upon the class-lecture. 
It was also found that meritorious and brilliant girls fall a victim of early marriage, eve-teasing, abduction, and rape. Again many boys drop out from education because of limited income source of their family. At an early age of life, they have to leave home in quest of normal job; they send money to the family after some months what they earn from his hard work. As a result, their dream remains a dream, which never comes out successful at all. This is very much practised at Thakurgaon. Many boys and girls fall victim of premature death due to the failure of English, Mathematics, and Science in the public examination. Many commit suicide by drinking poison, by burning fire, by throwing themselves on the railway lines, by leaving home without parental concerns. Such types of occurrences are published of the Daily Newspaper in Bangladesh. Again, those who cannot cut a good figure in the public examinations are rebuked not to pass in the examination. Finding no other alternative way, they find their ways in committing suicide.

However, difficulties, like lack of conversant English teachers, lack of English Language Club, Road Communication Problem, lack of safety for female students, lack of multimedia projector in the class, financial constraints, early marriage, and novice English teachers, politically recruited teachers and bribe were mostly noticed at some institutions at Thakurgaon.

These said problems create hindrance on the way of learning English Language among the Secondary Level Learners though data were collected from a single school due to time constraints and financial backup of the researcher. He didn't receive any financial support from any organization or any person. From his practical experiences, he carried out the current research project with a view to exposing the real picture of English language learning difficulties of his home district, like Thakurgaon.

\section{Conclusion}

As a theoretical type of work, the study focuses on the learning process and teaching methods that can be applied to minimize learning difficulties of young learners at the Secondary Level of Thakurgaon District who were not diagnosed with a learning disability, but still have significant difficulties learning a foreign language, like English. The aim of the paper is 'to provide mixed methods that would improve and encourage the young learners to learn English as a foreign language with minimum difficulties', the initial point arises from the hypothesis that the same teaching methods used with learning-disabled students can be practised to support students with learning difficulties and help them master English from the beginning of their studies.

Starting from the beginning, the foreign language learning process can be compared to the learning process of the first language. Children develop strategies (imitation, repetition, formulaic speech, and incorporation) that help them acquire their mother tongue; young learners go through the same process while learning a foreign language. However neither children nor young learners can do this alone, their parents and teachers need to take part in this process. Besides strategies, there are other instruments that facilitate acquisition of a foreign language. 
These instruments are the elements of teaching principles that enable the teachers to create suitable conditions for the young learners so that they can acquire a foreign language more easily. These principles are fundamental for further education process, which is based on teaching methods. Generally, these methods are provided to help the young learners of secondary level encourage their strengths and strengthen their weakness so that they can overcome their difficulties that cause frustration and their motivation to continue with foreign language learning.

In this point there are highly recommended methods also practised with SSC students, like multi-sensory techniques, discovery techniques, and metacognition. Concerning multi-sensory techniques their advantage is in the learners' sensory channels involvement into the learning process. Learners are made to use the stronger channels to support the weaker ones and thus, these techniques facilitate their brain to create the visual and auditory memories the tactile and kinetic ones. In terms of discovery techniques the advantage is in the self-discovery or awareness process when young learners tackle tasks on their own; they learn through what they have been detected by themselves. Metacognition also has its benefits, more preciously mnemonic devices that encourage young learners so that they can overcome their difficulties while learning a foreign language.

However, Bengali and English are different language systems and therefore, the problematic areas that cause the young learners of SSC level at Lahiri High School most difficulties at the beginning of learning a foreign language are mainly grammar, speaking skill, and vocabulary, because whereas grammar is not practised properly at school and home, English is, on the other hand, not as transparent. Bearing this in mind the study provides a set of example activities that can be improved to facilitate the young learners' mastery of English with minimum difficulties. At the same time, these activities demonstrate the practical usage of above mentioned teaching methods in learning English language.

\section{Recommendations}

1) This study showeds that ESL students in the sample believe that formal study of grammar is of crucial importance to language learning. The results of the study further confirm those of previous studies in terms of the overall role of grammar in the language classroom. The respondents also tend to believe that studying and practising grammar in the classroom help to improve students' communicative ability very quickly. It can be inferred that the teachers deem grammar learning as an important component to help their students achieve communicative competence. Clearly, their goal of helping their learners to attain a good ability, to communicate, or to involve into the formal study of grammar in the classroom.

2) The effective teaching of English Grammar at the SSC level may be ensured by the right kind of attitude towards teaching and learning English.

3) It has to be ensured that teachers implement their knowledge achieving through the proper training course.

4) New teaching methods have to be implemented. 
5) A suitable classroom environment is to be created.

6) Classes should be interesting so that the students can get motivated to learn English Grammar very easily.

7) Awareness should be raised in teaching and learning English Grammar with vocabulary and speaking.

8) Learners need more facilities to improve the basic knowledge of English. The teachers need proper time to get their students' knowledge implemented. Most of the English teachers of our country take the class using old method, they are not aware of the new method to teach students properly. They need to be well-trained. They need to gather knowledge on scientific \& technological teaching method in order that young learners can be able to improve English at Thakurgaon District. The environment in the classroom should be teacher-student oriented.

9) Learner needs more exercise books to practise daily.

10) To make the teaching of English more effective syllabus and curriculum should be well-modified. Further, recommendation is to add extra time for reading, writing, and speaking. In every week a compulsory class is a must on four skills. The concerned authority of the school should provide extra class so that they can improve basic knowledge of English language. When the teacher reads something in the class, teacher should motivate the students to read in the classroom. English teachers of each educational institution at Thakurgaon District should take pragmatic measurement so that learners can be able to emphasize upon English language.

11) Expert English teachers should be recruited and free and fair recruitment policy ought tobe be ensured.

12) Stipend must be provided for the poor and meritorious students.

13) Ultra-modern amenities should be ensured for the Secondary Level Learners.

\section{References}

Allen, E., \& Valette, R. (1997). Classroom Technique: Foreign Languages and English as a second Languages and English as a second Language. San Diego, Harecourt Brace Jovanovich.

Brown, H. D. (2000). Principle of Language Learning and teaching. New Jersey \& NY: Mcgraw-Hill.

Case, R. E., \& Taylor, S. S. (2005). Difference or Learning Language Disability? Answers from a linguistic perspective. ERIC Clearing House, 78(3), 127-130. http://eric.ed.gov/?id=EJ710918.

Cogan, J., \& Flecker, M. (2004). Dyslexia in Secondary School. A Practical Handbook for Teachers, Parents \& Students. London: Whurr Publishers Ltd.

Ganshow, L., \& Schneider, E. (2005). At-risk students and the study of a foreign language in school. Fact Sheet 25. 
Harmer, J. (2001). The Practice of English Language Teaching. Harlow: Longman.

Hasan, K. (2005). A Linguistic Study of English language curriculum at the Secondary Level in Bangladesh. A Communicative Approach to Curriculum Development. Language in India, 48, 1-240.

Krashen, S. D. (1981). Second Language Acquisition and Second Language Learning. Pergamon Press Inc.

Lokerson, J. (2006). Learning Disabilities: Glossary of Some Important Terms. Education Resources Information Center. Retrieved from http://www.eric.ed.gov

Reed, B., \& Railsback, J. (2003). Strategies and Resources for Mainstream Teachers of English Language Learners. Portland: Northwest Regional Educational Laboratory.

Schneider, E., \& Crombie, M. (2003). Dyslexia and Foreign Language Learning. London: David Fulton Publishers.

Tough, J. (1984). Young Children Learning Languages. In C. Brumfit, J. Moon, \& R. Tongue (Eds.), Teaching English to Children from Practice to Principle (pp. 213-227). London: Nelson.

Townend, J. (2006). Principles of Teaching - The DI Literacy Programme. The Dyslexia Institute. Retrieved from http://www.dyslexia-inst.org.uk/articles/prin_teach.htm

Wadlington, E., Jacob, S., \& Bailey, S. (1996). Teaching Students with Dyslexia in the Regular Classroom. Childhood Education. Gale Group.1-5.

Appendix One: Questionaire

1. In which class did you start learning English?

1. Pre-school

2. Primary School

3. Secondary School

4. College

5. What type of language did your English teacher use in the class?

1. Bangla for teaching

2. English for teaching

3. Hindi for teaching

4. None of above

5. Do you think that you are good at English?

1. Yes. I am good at English

2. No. I am not weak in English

3. Not at all

4. Neither good nor bad

5. Are you interested in ELT learning?

1. No. I have no interest

2. Yes. I have much eagerness 


\section{Macrothink

3. Yes. I am much interested

4. I have no interest in ELT

5. Do you like teaching career?

1. Yes. I like teaching

2. No. I dislike this profession

3. Not at all

4. I don't think so

5. Do you think teachers in Bangladesh are very good at English?

1. Yes. I think so

2. No. I don't think so

3. Some teachers are expert, but others aren't

4. Teachers may be good at English if they receive training course

5. Are you sure that English is a must for a job?

1. I am not sure of it

2. I am sure that an English knowing person will get a good job

3. English is essential for a job

4. English is not important for getting a job

5. Do you support ELT course is essential for all?

1. No. I don't support

2. Yes. I support

3. I have no idea of ELT course

4. ELT course is not helpful for all

5. Do you think a mother should learn English?

1. No. I don't think so

2. Yes. I think each mother should learn English

3. English is a must for a mother

4. English is not essential for a mother

5. Do you think a teacher can show you the right path?

1. No. I don't think so

2. Yes. I support this idea

3. A teacher can't guide us

4. A teacher is the maker of a nation

5. To go abroad, do you think you should learn English?

1. No. I don't think so

2. Yes. I think English is very essential for going abroad

3. We need not learn English at all

4. None of above 


\section{Macrothink

5. To learn English what complexities do you suffer most?

1. English is not our mother tongue

2. Environmental problem

3. We have an ample opportunity to learn English

4. We don't get any opportunities of learning English from anybody

5. Do you think English environment is a must?

1. No. I need not English environment

2. Yes. I think English environment is very important

3. Both $b$ \& d

4. English environment is necessary for a learner

\section{Do you think students have no interest in ELT?}

1. They have no interest in English

2. They have interest, but they don't get opportunity

3. They are weak in English, so they have no interest at al.

4. They have interest, but they don't bother to learn English

5. Do you think teachers are not alert in motivating students for SL

1. No. I don't think so

2. EFL course is not necessary for students, so teachers don't motivate them at all

3. Teachers have no time to motivate their learners

4. I think teachers should be alert in motivating students for SL

\section{Appendix Two: Interview}

Interviewer: What is your name?

Interviewee: My name is Abu Hena

Interviewer: What is your school's name?

Interviewee: The name of my school is Lahiri High School.

Interviewer: Which subject are you interested to learn and which level?

Interviewee: I am interested to learn English at SSC level.

Interviewer: Do you know about four skills of English?

Interviewee: Yes. I know about four skills of English Language.

Interviewer: What are they?

Interviewee: Reading, writing, speaking \& listening 
Interviewer: How did your teacher teach English language?

Interviewee: My teacher taught us English through black board. Sometimes he moved his hands \& mouth while teaching us.

Interviewer: Do you think English is essential for a job?

Interviewee: Yes. I think English is essential for a job.

Interviewer: To learn English what complexities do you suffer most?

Interviewee: To learn English complexities which we have to suffer most are pronunciation, speaking \& writing problem.

Interviewer: Do you think teachers are not alert in motivating students for SL and why? Interviewee: Yes. I think so. Teachers are not alert in motivating students for SL. They are not good at English language, because they don't try to do better.

Interviewer: What complexities do you face in learning a foreign language?

Interviewee: Complexities which I face in learning a foreign language are pronunciation, vocabulary, speaking \& writing problem. I don't get opportunities of learning English environment where I reside.

Interviewer: What do you think about English language?

Interviewee: I think English is an international language. English is used all over the world. To get a good job, English is a must. Without English we can't think of our existence. We need to develop our knowledge of English day by day.

Interviewer: What is your recommendation to overcome English learning complexities? Interviewee: I recommend that we should practise English every day, especially grammar, vocabulary, writing, and speaking skill. We should bear in mind that practice makes a man perfect.

\section{Copyright Disclaimer}

Copyright reserved by the author(s).

This article is an open-access article distributed under the terms and conditions of the Creative Commons Attribution license (http://creativecommons.org/licenses/by/3.0/). 